\title{
STUDENT'S SELF-CONCEPT PROFILES IN PROBLEM POSING ACCORDING TO COGNITIVE STYLES: DEVELOPING AN EVIDENCE BASE FOR BEST PRACTICE OF E- LEARNING IN MATHEMATICAL ECONOMICS COURSE AT PAMULANG UNIVERSITY
}

\author{
Angga Hidayat \\ University of Pamulang \\ Email: angga1203hidayat@gmail.com
}

\begin{abstract}
Abstrak
Penelitian ini merupakan penelitian kualitatif dan bersifat eksploratif yang bertujuan untuk mendeskripsikan konsep diri mahasiswa dalam pengajuan masalah matematika bisnis ditinjau dari perbedaan gaya kognitif, yaitu field dependent dan field independent. Subjek penelitian ini terdiri dari dua mahasiswa , berjenis kelamin perempuan. Penelitian dimulai dengan menentukan subjek penelitian menggunakan instrument GEFT. Perbedaan gaya kognitif, kesamaan jenis kelamin, kemampuan berkomunikasi dan kesediaan mahasiswa juga menjadi pertimbangan peneliti untuk memilih subjek, kemudian dilanjutkan dengan memberikan tugas pemecahan masalah, wawancara dan pengamatan. Pengecekan keabsahan data menggunakan triangulasi waktu. Berdasarkan hasil analisis data, dapat disimpulkan bahwa subjek bergaya kognitif field dependent berusaha dalam memecahkan masalah matematika bisnis walau menghadapi beberapa kesulitan dan merasa tidak yakin dapat memecahkan masalah matematika bisnis dengan benar. Selain itu, subjek bergaya kognitif field dependent merasa gugup, tegang dan khawatir tetapi tidak menunjukan perubahan fisiologis dan menjelaskan secara garis besar tentang pemecahan masalah matematika bisnis. Di sisi lain, subjek bergaya kognitif field independent berusaha terus dalam memecahkan masalah matematika bisnis walau menghadapi kesulitan dan merasa yakin dapat memecahkan masalah matematika bisnis. Subjek bergaya kognitif field independent tidak merasa gugup, tegang dan khawatir tetapi mengeluarkan keringat pada telapak tangan dan menjelaskan secara terperinci tentang pemecahan masalah.
\end{abstract}

Kata Kunci: Konsep Diri, Kecemasan, Pemecahan Masalah, Gaya Kognitif

\begin{abstract}
This research was a qualitative research with explorative approach. The objective of the research was to describe self-concept of university student in posing problem of e-learning course based on the differences of cognitive style, namely field dependent and field independent. The research's subjects were four students in $1^{\text {st }}$ semester, Pamulang University. The research began by determining the subject using instrument of GEFT. The difference of cognitive style, the similarity of gender, communication ability, and the student's availability also became researcher's consideration in choosing subject itself, then continued with problem posing assignment, interview and observation. Checking validity of data used triangulation of time. Results that could be found from this study were students who have field independent cognitive style tried harder to pose mathematical economics problems. Moreover, they could pose the problems in wider variety. In contrast, students who have field dependent cognitive style thought rapidly and with simplicity. That being said, they completed tasks with no effort. This information will likely impact how lecturers teach online class. Furthermore, it also affects future research correlated to problem posing especially in e-learning course.
\end{abstract}

Keywords: Self-Concept, E-learning, Problem Posing, Cognitive Style.

\section{INTRODUCTION}

One of the issues which received much emphasis and consideration in recent years is e-learning process. One of the best reasons clearly explaining this phenomenon is referred to an assumption that distance learning improves students' performance in understanding courses more than conventional learning method. Indeed it would seem to be students learn independently. It is a must for them to find a solution of problems given lecturers by themselves. A consequence of this regulation has been a 
substantial increases in observing more about theme that are discussing on the web. Clearly though, the more they search, the more they discover the problem discussing on the web.

Online learning can be applied in many courses including mathematics. Mathematics as a basic science holds an important role in developing science and technology. Mathematics is learnt in every level of education, including in university. By learning mathematics, students in university are hoped to increase significantly their ability in solving problems related to their circumstances in workplace. Moreover, there are many branches of mathematics that relatively support citizen to overcome problems in workplace. One of the branches is mathematical economics. This kind of branch is useful to assist students in university who learn accounting to find solutions in economic world.

Slavin (2006) explained that opinion about mathematics is difficult to learn could affect student's attitude in solving problem correlated to mathematics. As a result, this would appear that students who have just graduated from university would face many problems at workplace especially for those who working in accounting field jobs. This can be explained to the fact that people who choose a career in accounting require basic skills of mathematics to fulfill their job responsibilities.

The relationship between problem solving and problem posing has been the subject of many research studies. one of the research explaining the fact that students who were better in non-routing problem solving were better problem posers (Kaur, Yeap \& Kapur, 2009). Moreover, problem-solving ability of American middle school students highly correlated with their ability to pose semantically complex problems in one type of problem-posing task (Silver \& Cai dalam Kaur, Yeap, \& Kapur, 2009). In a series of investigations on third, fifth and seventh graders in Australia, there was a relationship between problem solving and problem posing. In particular, competence in routine problem solving is associated with posing of computationally complex, but not necessarily structurally complex, problems (English dalam Kaur, Yeap, \& Kapur, 2009). Competence in novel problem solving is associated with posing of structurally complex problems . Among Singapore students, it was found that good problem solvers had significantly higher problem-posing scores than poor problem solvers. In addition, it was found that when the students had no prior experience in problem posing, the relationship between problem solving and problem posing was not dependenton grade level. That being said, research on problem posing during and after problem solving is comparatively less established.

Based on explanations above, researcher has an intention to do a research about student's selfconcept profiles in problem posing according to cognitive styles: developing an evidence base for best practice of e-learning in mathematical economics course at Pamulang University.

Based on explanations in background of the research, then it can be concluded trere are some problems of the research, namely:

1) E-learning or distance education is a new learning and teaching model. Consequently, it needs more research to develop it to be more effective and efficient.

2) Many students especially in accounting department think that mathematical economics is a difficult subject to learn.

3) An assumption that mathematical economics is a difficult subject leads to low skill of students in posing the problems. Needless to mention, problem posing is one of learning methods that can significantly improve creativity. Moreover, the fact that creativity is needed more at workplaces nowadays.

4) Many students have low self-concept. Low self-concept affect their jobs in the future since selfconcept is related to creativity.

5) There are many cognitive styles that people have. As a result, there are many ways how people think. Lecturers should teach according to cognitive style that their students have to maximize the learning. 


\section{RESEARCH METHOD}

Researcher uses qualitative research that describe self-concept in mathematical economics problem posing with different cognitive styles. The researcher uses mathematics business questions, questionnaires and interview to investigate the description.

Total of 2 participants take part in the study, all females. 1 student who has field independent cognitive style and 1 student who has field dependent cognitive style. Subjects of the research are students in University of Pamulang. Criteria for inclusion in the study of the participants are in the second semester, and being learning business mathematics. Researcher is a main instrument in a qualitative research. Moreover, researcher do the research immediately to all processes. Besides, there are other instruments such as:

1) Mathematics achievement instrument

This instrument is used to investigate student mathematics achievement. The instrument consist of ten questions based on learning materials taught in first semester. After the instrument is compiled orderly, it will be given to the competent validator to be validated.

2) Problem posing instrument

This instrument is made to describe self-concept with different achievement. The instrument consist of three questions developed by researcher then consulted by two validators.

3) Self-concept instrument

Self-concept instrument used in the research is Mathematics Self-Concept Scale (MSC) developed by Georgey (1984). The instrument consists of 27 items to assess the mathematics self-concept.

Researcher uses data analysis technique based on step of qualitative data analysis according to Miles and Huberman which is as follows:

1) Data reduction

Reduction of the research is a selection process by simplifying datum gotten in the research.

2) Data display

Display of the research is data that written orderly to help the researcher in understanding the data.

3) Conclusion

Conclusion is conducted with conclusion of the data about self-concept mathematical economics problem posing

\section{RESULT AND DISCUSSION}

The research instrument used to obtain self-concept image of university students consists of Embedded Figures Test Group (GEFT), business mathematics problem posing test, self-concept interview guide. Prior to use in the research, the instruments and their validation sheets were consulted with supervisors and then validated by experts. The following will explain more about the process of instrument compilation and validation.

\section{1) Group Embedded Figures Test (GEFT)}

Group Embedded Figures Test (GEFT) is a test instrument developed by Witkin et al used to categorize individuals into categories of FI and FD cognitive styles. The instrument consists of simple and complex geomeattempt builds, then subjects are asked to look for simple shapes that are in complex shapes by thickening simple shapes. This GEFT test is an instrument developed by Witkin et al. The instruments used in this study are adapted from the original English-language instrument. Thus, this instrument can be used immediately.

2) Business mathematics Problem Posing Test (BMPPT)

Business mathematics Problem Posing Test (BMPPT) is designed to reveal self-concept of university students in posing business mathematics problems according to cognitive style differences namely FD and FI. Before given to the subjects of the research, BMPPT was consulted 
by supervisor. After obtaining approval from the supervisor, then the instrument was validated by the validators.

3) Self-Concept Interview Guideline

Interview was conducted to obtain data about self-concept of university student directly. Research subjects were given problem posing and were asked to pose it. Subjects were interviewed before, during and after e-learning. Therefore, researchers need to develop interview guidelines to avoid missed data during the interview process and the interview was recorded with a recorder. Before being used as a guideline in interviewing the research subjects, the interview guideline were consulted with supervisors and validated by two lecturers of business mathematics, a psychologist.

The cognitive style test was distributed in 4 classes. Based on GEFT result, researcher obtained two students who are capable of equivalent to different cognitive styles, namely field dependent and field independent. The result of cognitive style test for 100 students in Pamulang University is as follows.

Table 1 Distribution of Cognitive Styles

\begin{tabular}{lll}
\hline \multicolumn{2}{c}{ Cognitive Style } & \multirow{2}{*}{ Number } \\
\cline { 1 - 2 } Field Dependent $(\mathrm{FD})$ & Field Independent $(\mathrm{FI})$ & \\
\hline 68 & 32 & 100 \\
\hline
\end{tabular}

Based on the data in Table 1 it is describen that from 100 students who follow GEFT, there are 68 students (68\%) who have cognitive style FD and 32 students (32\%) who have FI cognitive style. From the group of students who have FD cognitive style is selected a student who has high mathematical skills and can communicate well, and from groups of students who have FI cognitive style is selected a student who has the same ability with a student selected from the FD group, namely high-ability and can communicate well, as shown in Table 2 below.

Table 2 List of Research Subjects

\begin{tabular}{lllc}
\hline Sex & Score & Group & Name \\
\hline F & 5 & $F D$ & Subject of field dependent $($ FD) \\
F & 13 & $F I$ & Subject of field independent (FI) \\
\hline
\end{tabular}

Furthermore, to facilitate the coding, student who has FD cognitive style is called SD, while the representative of the FI group is called SI.

Table 3 Triangulation of SI Self-Concept Data on the dimensions of expectations

\section{Interview on BMPPT 1 Interview on BMPPT 2}

a) Expecting improve mathematical abilities by studying better. Subject recognizes difficulties in learning business mathematics. Subjects use training strategies in business mathematics more often in order to become understand more in business mathematics. [(SI1115), (SI1116), (SI1119)]

b) Attempt to continue working on business mathematics despite facing difficulties when solving the problem of algebra, namely the difficulty in determining the next steps after turning math problem into a equation of business mathematics. [(SI1133), (SI1136)] a) Expecting be able to improve mathematical abilities by studying more. The subject explain the difficulties he experienced when studying business mathematics, namely algebra. It sometimes affects the subject feeling dizzy. Subject use the exercise strategy, then she can overcome the difficulties she face. [(SI2108), (SI2110), (SI2111)]

a. Attempt to continue working on business mathematics even though facing difficulties when solving the problem of algebra, namely the coefficients on several variables are greater than one which makes the subject more confused in solving 


\begin{tabular}{ll}
\hline \multicolumn{1}{c}{ Interview on BMPPT 1 } & \multicolumn{1}{c}{ Interview on BMPPT 2 } \\
\hline & $\begin{array}{l}\text { problems. [(SI2125), } \\
\text { (SI2129)] }\end{array}$ \\
b. Expect other people to appreciate the & c) $\begin{array}{l}\text { Expect other people to appreciate the } \\
\text { results of their work because the } \\
\text { results of their work because the } \\
\text { subject feels that she has tried hard to } \\
\text { pose the problem of business } \\
\text { mathematics given despite facing } \\
\text { some difficulties such as determining } \\
\text { the variables that must be transferred } \\
\text { to obtain the desired results. [(SI1150), } \\
\text { (SI1151), (SI1152)] }\end{array}$ \\
\hline
\end{tabular}

Based on above description (BMPPT 1 and BMPPT 2), it can be concluded that the research subject and the arguments are consistent. Furthermore, it can be concluded that the data SI self-concept on the dimension of expectation is valid.

Table 4 Triangulation of SI Self-Concept Data on the dimensions of estimation

\begin{tabular}{|c|c|c|}
\hline & Interview 1 & Interview 2 \\
\hline 1) & $\begin{array}{l}\text { believing that be able to pose the } \\
\text { problem of business mathematics } \\
\text { given even though the subject judges } \\
\text { that the questions presented are } \\
\text { difficult because she has studied } \\
\text { business mathematics and consider } \\
\text { that business mathematics is a material } \\
\text { that is easy to learn. [(SI1121), } \\
\text { (SI1122), (SI1123)] }\end{array}$ & $\begin{array}{l}\text { 1) Believe in being able to solve business } \\
\text { mathematics problems given despite } \\
\text { having difficulties in learning business } \\
\text { mathematics when transferring } \\
\text { business mathematics because he has } \\
\text { studied business mathematics and } \\
\text { considering business mathematics is } \\
\text { an easy-to-understand material. } \\
\text { [(SI2123), (SI2125), (SI2128)] }\end{array}$ \\
\hline 2) & $\begin{array}{l}\text { Comparing ability to pose problems } \\
\text { with her classmates. Subjects make } \\
\text { predictions can she can solve problems } \\
\text { better and faster than almost all } \\
\text { classmates because the subject is able } \\
\text { to do the problem better and faster } \\
\text { when working on the questions given } \\
\text { by her math teacher. [(SI1153), } \\
\text { (SI1154)] }\end{array}$ & $\begin{array}{l}\text { Comparing ability to pose problems } \\
\text { with her classmates. Subjects expect } \\
\text { that she can to pose business } \\
\text { mathematics problems faster than most } \\
\text { classmates because the subject can } \\
\text { work on questions faster when the } \\
\text { math teacher gave questions to } \\
\text { students in her class [(SI2145), } \\
\text { (SI2146)] }\end{array}$ \\
\hline
\end{tabular}

Based on above description (BMPPT 1 and BMPPT 2), it can be concluded that the research subject and the arguments are consistent. Furthermore, it can be concluded that the data SI self-concept on the dimension of estimation is valid.

Tabel 5 Triangulation of SD Self Concept Data in the Dimension of Expectation

\section{Interview 1}

a. Subject do not expect to become better in order to improve math skills. Subjects recognize difficulties in studying business mathematics, namely adding and subtracting fractions from business mathematics. Subject was not motivated to overcome the mathematical difficulties Sheila experienced because they thought mathematics was a

\section{Interview 2}

a) Subject do not expect to become better in improving mathematical abilities. Subject understands her weaknesses in learning business mathematics, namely fractions of business mathematics. Subject is not motivated to overcome his weaknesses because mathematics is not a favoured subject by the subject [(SD2112), (SD2113), (SD2114)] 


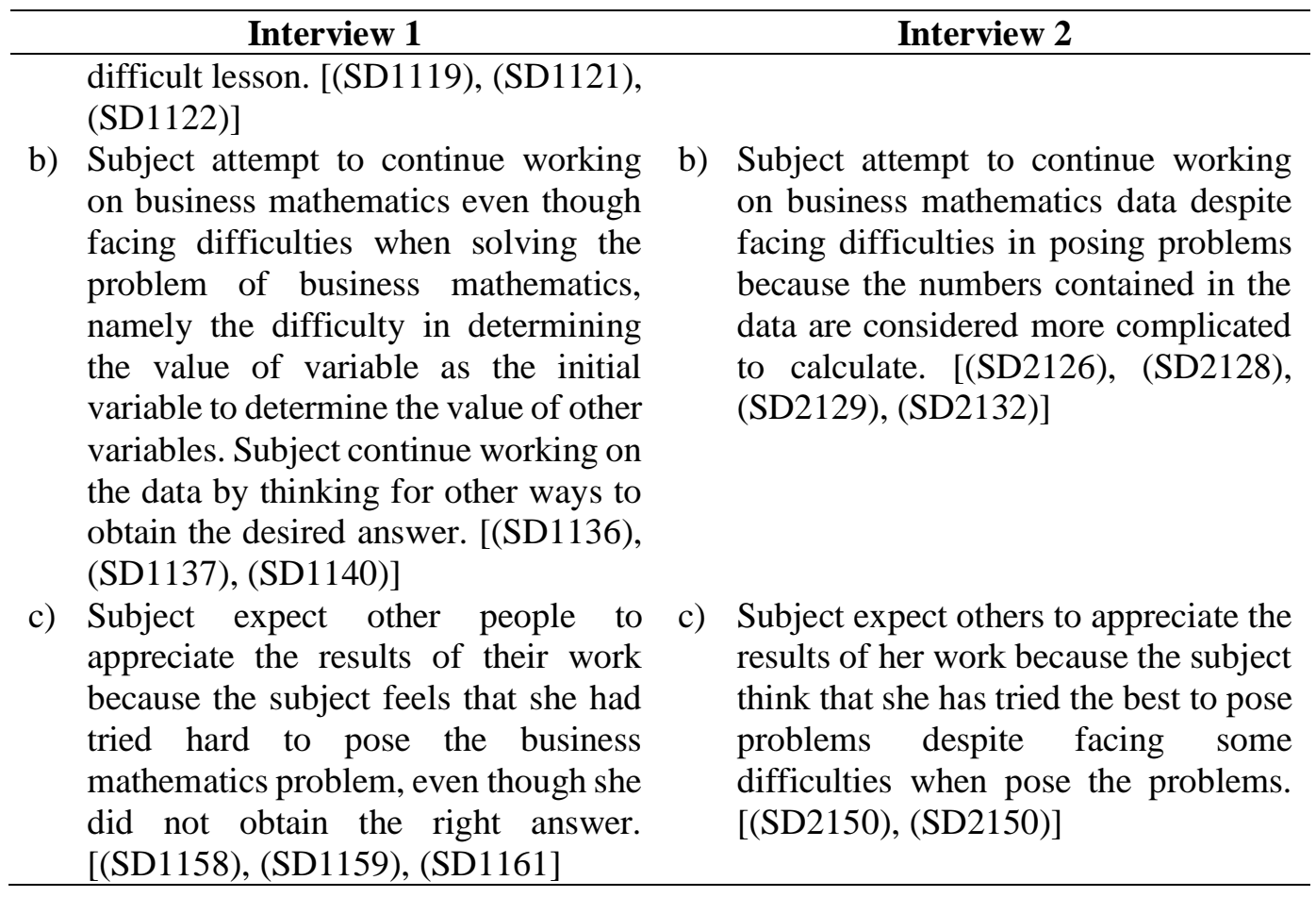

Based on the two exposures above (BMPPT 1 and BMPPT 2), it can be defined that the selfconcept revealed by the research is consistent. Moreover, it can be concluded that the SD self concept data on the dimension of expectation is valid.

Tabel 6 Triangulation of SD Self Concept Data in the Dimension of Estimation Interview 1 Interview 2

a) Subject does not believe that she can pose business mathematics problems given because subject considers that the data presented is difficult. The subject has already studied business mathematics and considers that business mathematics is a difficult subject to learn. [(SD1126), (SD1138), (SD1139)]

b) Subject compares ability in posing problems with classmates. Subject predicts that she can pose problems in the middle order that she can pose the problem if the classmates are asked to work on the same problem. [(SD1162), (SD1163)]

a) Subject does not believe that she can pose business mathematics problems given because the subject considers that the questions presented is a difficult lesson. Subject has already studied business mathematics and considers business mathematics a difficult teaching material because there are letters in the calculation. [(SD2118), (SD2130), (SD2131)]

b) Subject compare ability in posing problems with classmates. Subject predicts can solve problems not in the first order to complete the questions but also not the last to pose them (SD2153)

Based on the two exposures above (TPM 1 and TPM 2), it can be seen that the things revealed by the research subjects and their arguments tend to be consistent. Thus it can be concluded that the SD self concept data on the assessment dimension is valid. 


\section{CONCLUSIONS}

1) Self-concept of students with Cognitive Style FI in posing business mathematics problems

Subject expected to improve business mathematics with learning business mathematics problems more often. The subject also tried to continue to pose business mathematics problem despite facing some difficulties. This is marked by mentioning the data that is known and asked in the data by explaining each data by her own sentence. Subject pose problem-planning by explaining that the problem can be posed by assuming the data into word problems. In addition, the subject continued her efforts to pose business mathematics problems despite faced difficulties. The subject also checked her work before published it to the web. In addition, the subject expected that the results of his work will be appreciated by others.

Subject felt confident that she could pose business mathematics problems. This was characterized by distinguishing between difficult and easy questions because she had studied business mathematics and considered business mathematics as an easy subject but have difficulty especially for friction word problems.

Subject was not worried about failing in posing the problem since she had checked the results of the work before publihed it to web. Subject predicted that she could pose the problem better and faster than the average classmates since the subject commonly could pose problem better and faster when learning mathematics.

2) Self-concept of students with Cognitive Style FD in posing business mathematics problems

Subject did not expect that she could improve her mathematical abilities, but subject attempted to continue to pose business mathematics problems despite facing some difficulties. This was contributed to the fact that she explained that is known and asked about the problem by explaining each data by her own sentences. Subject explained problemposing plan by explaining that the problem could be posed by assuming the data as variables then wrote word problems. In addition, the subject continued her task to pose business mathematics problems despite experiencing difficulties, but the subject did not check the results of her task before published to the web. In addition, the subject expected that others will appreciate the result of her work.

Subject did not feel confident in posing business mathematics problems. This was contributed to the fact that she understood difficult and easy questions because she had studied business mathematics and considered business mathematics as a difficult subject and faced difficulties when calculating fractions in business mathematics. Subject was worried about failing to pose business mathematics problems and she did not check the result of the work before published it to the web. Subject predicted that subject could pose problem better and faster than the average classmate since subject often pose problem better and faster when learning mathematics.

\section{DAFTAR PUSTAKA}

Andong, Andi. Proses Berpikir Siswa yang Memiliki Gaya Kognitif Field Dependent dan Field Independent dalam Memecahkan Masalah Matematika Divergen. (Unpublished Doctoral Dissertation), Surabaya State University. (2011).

Altun, Arif. "Undergraduate Student's Academic Achievement Field Independent/ Independent Cognitive Style And Attitude toward Computer". Educational Technology and Society 2006, Vol. 9. No. 1. 289-297. http://www.ifets.info/journals/9 1/23.pdf (2006).

Calhoun, J. F., \& Acocella, J. R. Psychology of Adjustment Human Relationship. New York: McGraw-Hill. (1990) 
Ellis, R. A., Ginns, P., \& Piggot, L. E-learning in Higher Education: Some Key Aspects and Their Relationship to Approaches to Study. Higher Education Research \& Development, 28(3), 303. Retrieved from informaworld.com/10.1080/072943609028399. (2009)

Governors Sate University, Center for Online Learning and Teaching. E-learning Glossary. Retrieved from govst.edu/elearning/default.aspx. (2008)

Guri-Rosenblit, S. Distance Education and E-learning: Not the Same Thing. Higher Education, 49(4), 467-493. (2005)

Guvercin, S., \& Verbovsiy, V., The Effect of Problem Posing Tasks Used in Mathematics Instruction to Mathematics Academic Achievement and Attitude toward Mathematics. International Online Journal of Primary Education vol 3 issue 2. (2014)

Jereb, E., \& Smintek, B. Applying Multimedia Instruction in E-learning. Innovations in Education \& Teaching International, 43(1), 15-27. (2006)

Kaur, Berinderjeet, Yeap, Ban Har \& Kapur, Manu. Mathematical Problem Solving. Singapore: World Scientific. (2009)

Koohang, A. \& Harman, K. Open Source: A Metaphor for E-learning. Informing Science Journal, 8, 75-86. (2005)

Lee, Mark J. W. \& McLoughlin, Catherine. Web 2.0-Based E-Learning: Applying Proceedings of the $8^{\text {th }}$ International Conference on Advances in Web Based Learning Social Informatics for Tertiary Teaching. (2011)

Li, F. W., Lau, R. W., \& Dharmendran, P. A three-tier Profiling Framework for Adaptive Elearning., Aachen. (2009)

Liao, H. \& Lu, H. Richness Versus Parsimony Antecedents of Technology Adoption Model for E-learning Websites. Retrieved from dx.doi.org/10.1007/978-3-540-85033-5_2. (2008)

Marques, P. Definition of e-learning. Retrieved from pangea.org/peremarques.

Markus, H. \& Nurius, P. "Possible Selves". American Psychologist. 41(9): 954-969. (1986)

Ministry of Communication and Technology of New Zealand. Digital Strategy of the Ministry of Communication and Technology. Retrieved from digitalstrategy.govt.nz/resources/glossary-of-key-terms/. (2008)

Mulyono. Proses Berpikir Mahasiswa Field Independent dan Field Dependent dalam Merekonstruksi Konsep Grafik Fungsi Berorientasi pada APOS. (Unpublished Doctoral Dissertation), Surabaya State University. (2011)

Myers, David G. Social Psychology (10 ${ }^{\text {th }}$ ed.). New York: McGraw-Hill Higher Education. (2009)

Sangra, A., Vlachopoulus, D., \& Cabrera, N. Building an Inclusive Definition of E-learning: An Approach to the Conceptual Framework. Irrodl vol 13, no 2. (2012) of a Communities of Inquiry in Online and Blended Learning Environments. Computers \& Education vol 55 issue 4 1721-1731. (2010)

Shea, P., \& Bidjerano, T., Learning Presence: Towards a Theory of Self-Efficacy, SelfRegulation, and The Development

Shavelson, Richard J. and Bolus, Roger. Self-Concept: The Interplay of Theory and Methods. Journal of Educational Psychology, Vol. 74, No. 1, 1982 pp. 3-7. (1981)

Singer, Florence Mihaela, \& Ellerton, Nerida F. Mathematical Problem Posing From Research to Effective Practice. New York: Springer. (2015)

Slavin, Robert E. Educational Psychology : Theory and Practice $6^{\text {th }}$ edition. Massachusetts : Allyn and Bacon Publisher. (2006)

Stoyanova, Elena. Empowering Students' Problem Solving via Problem Posing: The Art of Framing 'Good' Questions. Eric. (2000)

Wenglinsky, Harold. Measuring Self-Concept and Relating It to Academic Achievement: Statistical Analyses of the Marsh Self-Description Questionnaire. New Jersey: Educational Testing Service. (1996) 